\title{
Marriage and Divorce
}

\section{Andria Pragholapati}

In-Law No. 1 of 1974 in article 1, marriage is an inner and outer bond between a man and a woman as husband and wife with the aim of forming a happy and eternal family (household) based on the Godhead of the Almighty. The law does not specifically explain the meaning of divorce. In the Big Indonesian Dictionary, Divorce comes from the syllable of divorce, and divorce according to language means separation, concerning divorce between husband and wife, division, divorce.

Law No. 1 of 1974 Article 38 explains marriages can be terminated because of death, divorce, and the court's decision. Furthermore, Article 39 explains that divorce can only be carried out in front of the Trial Court after the relevant Court tries and fails to reconcile the two parties, to divorce there must be enough reasons, that between the husband and wife will not be able to live in harmony as husband and wife, and the procedure the method of divorce before a court hearing is regulated in separate laws. Then divorce is permitted, although in principle this law complicates divorce. This principle is an effort to reduce and reduce the number of divorces and that divorce is not used as a last alternative by husband and wife if there is a fight in the household.

Divorce (divorce) is an event of official separation between husband and wife and they are determined not to carry out their duties and obligations as husband and wife. They no longer live and live together, because there is no official bond. Those who have divorced but do not have children, separation does not have a psychological traumatic effect on children. But those who already have children, of course, divorce creates psycho-emotional problems for children. On the other hand, it is possible that children born as long as they live as husband and wife will be included with one of their parents whether they follow their father or mother (Dariyo, 2004).

Divorce results in emotional setback (emotional setback). Divorced people may blame themselves for the misfortune (divorce). Indicators of mental health that are affected by divorce are related to depression, anger, low self-esteem, and anxiety. (Goldstein, 2008). According to Kurdek, (1990); Hung, Kung, \& Chan, (2004) in Sharma (2011), divorce brings emotional and mental impacts on individuals, especially women. Women are considered as a strength in the family, believed to be responsible for whatever wrongdoing is done, more coping in the family, take greater responsibility in marriage, and therefore divorce is a greater failure than men.

Divorce has a negative impact which is a traumatic experience in one of the life partners (male or female) and instability in work. Divorce has a negative impact on mental and physical health (Waite \& Gallagher, 2000; Hughes \& Waite, 2009; Bronselaer, De Koker \& Van Peer, 2008; Zulkarnain \& Korenman, 2015). Divorce is associated with an increased risk of disability, mental health problems, decreased health, and mortality (Zulkarnain \& Korenman, 2015). Divorce gives rise to transitional changes to someone such as changes in responsibilities, worsening financial situation, lack of social support, changes in health behaviors that are often perceived as stressful 
and have long-term negative impacts on one's health status (Bronselaer, De Koker, and Van peer, 2008).

The bad effects of divorce on mental health are stress, depression, and anxiety. Depression is a depressed state, due to a great disappointment (death, divorce, bankruptcy) or personal loss (the death of a lover) naturally becoming depressed. His soul was depressed with symptoms of feeling very sad, hopeless, and lost of excitement, feeling tired and tired, no appetite, and insomnia. And also mentally disturbed, often pensive with delusional thoughts, reduced concentration, uncertainty, and difficulty to make decisions (Dariyo, 2003).

*Nursing Department, Universitas Pendidikan Indonesia

Andria.pragholapati@upi.edu

\section{REFERENCES}

Ade, M.S., Tjutju, Pragholapati, A., 2016. GAMBARAN KUALITAS HIDUP PADA LANSIA DI BALAI PERLINDUNGAN SOSIAL TRESNA WERDHA CIPARAY BANDUNG TAHUN 2016.

http://ejurnal.stikesbhaktikencana.ac.id/file.php?file=preview_mahasiswa\&id=532\&cd=0b2173f f6ad6a6fb09c95f6d50001df6\&name=JURNAL\%20SAKINAH\%202016.pdf.

Andria Pragholapati, M.L., 2017. HUBUNGAN MASALAH KESEHATAN JIWA DENGAN STRATEGI KOPING SESEORANG YANG MENGALAMI PERCERAIAN DI KOTA BANDUNG, in: Seminar Nasional Dan Workshop Keperawatan “Penguatan Profesi Keperawatan Dalam Peningkatan Pelayanan Keperawatan" Continuum of Care Dari Ketergantungan Menuju Kemandirian Hidup Yang Berkualitas. ISBN: 978-602-14422-8-9.

Andria Pragholapati, R., 2018. DEVELOPMENT OF THE INDONESIAN NATIONAL QUALIFICATIONS FRAMEWORK FOR NURSING CURRICULUM, in: International Conference on Education and Regional Development 3rd (ICERD) 2018 "Curriculum for Generation of Discruptive and 4th Industry Revolution Era.” p. 44.

Andria Pragholapati, R.M., 2017. HUBUNGAN BULLYING DENGAN KEMAMPUAN SOSIAL PADA REMAJA DI SMK MVP KOTA BANDUNG TAHUN 2017, in: Konferensi Nasional Keperawatan Kesehatan Jiwa XIV Di Kalimantan Selatan Tahun 2017.

Andria Pragholapati, T., 2018. HUBUNGAN PENGGUNAAN SMARTPHONE DENGAN KUALITAS TIDUR PADA REMAJA DI SMK X BANDUNG, in: Konferensi Nasional Keperawatan Kesehatan Jiwa XV Di Hotel Four Point By Sheraton Makassar Sulawesi Selatan. pp. 1-7.

Ardiana, F., Nurlianawati, L., Pragholapati, A., 2016. Gambaran Fungsi Kognitif Pada Lanjut Usia (Lansia) Di Panti Jompo Muhammadiyah dan Yayasan Pondok Lansia Tulus kasih.

Ariani, A., Pragholapati, A., Pratama, A.S., 2020. Information Communication Technology (ICT) In Midwifery Education: A Review of the Literature, in: The 3rd International Seminar on 
Global Health (ISGH) "Technology Transformation in Health Care for Better Life" Bandung, West Java, Indonesia. http://repository2.stikesayani.ac.id/index.php/isgh3/article/view/352, pp. 66-69.

Ismawati, Y., Pragholapati, A., 2020. KEJADIAN GASTRITIS DI DESA CINUNUK WILAYAH KERJA PUSKESMAS CINUNUK KABUPATEN BANDUNG.

Ismawati, Y., Sumbara, Pragholapati, A., 2018. HUBUNGAN POLA MAKAN DENGAN KEJADIAN GASTRITIS DI DESA CINUNUK WILAYAH KERJA PUSKESMAS CINUNUK KABUPATEN BANDUNG.

Pragholapati, A., 2020. Self-Efficacy Of Nurses During The Pandemic Covid-19.

Pragholapati, A., 2020. COVID-19 IMPACT ON STUDENTS. osf.io.

Pragholapati, A., 2020. RESILIENSI PADA KONDISI WABAH COVID-19.

Pragholapati, A., 2020. STRES KERJA PERAWAT YANG BEKERJA DI UNIT GAWAT DARURAT (UGD) RUMAH SAKIT AL ISLAM (RSAI) BANDUNG.

Pragholapati, A., 2020. MOTIVASI KERJA PERAWAT DI RUANG RAWAT INAP RSUD MAJALAYA KABUPATEN BANDUNG.

Pragholapati, A., 2020. MENTAL HEALTH IN PANDEMIC COVID-19.

Pragholapati, A., 2020. RESILIENSI PERAWAT YANG BEKERJA DI UNIT GAWAT DARURAT (UGD) RUMAH SAKIT AL ISLAM (RSAI) BANDUNG.

Pragholapati, A., 2020. NEW NORMAL “INDONESIA” AFTER COVID-19 PANDEMIC.

Pragholapati, A., 2019. THE EFFECT OF BRAIN GYM TO THE LEVEL OF DEPRESSION IN GERIATRIC AT BALAI PERLINDUNGAN SOSIAL TRESNA WERDHA CIPARAY BANDUNG. J. Sk. Keperawatan 5, 128-146.

Pragholapati, A., Munawaroh, F., 2020. RESILIENSI PADA LANSIA. J. Surya Muda 2, 1-8.

Pragholapati, A., Ulfitri, W., 2019. Gambaran Mekanisme Coping pada Mahasiswa Program Studi Sarjana Keperawatan Tingkat IV yang Sedang Menghadapi Tugas Akhir di Sekolah Tinggi Ilmu Kesehatan X Bandung. Humanit. J. Psikol. 3, 115-126.

Prasetyo M, D., Nurlianawati, L., Pragholapati, A., 2017. GAMBARAN TINGKAT KECEMASAN PADA PASIEN PRE OPERASI FIBROADENOMA MAMMAE DI RUANG GUNTUR RUMAH SAKIT TK II DUSTIRA CIMAHI TAHUN 2017.

http://ejurnal.stikesbhaktikencana.ac.id/mahasiswa.php?detail=mahasiswa\&id ....

Rahmawati, S.D., Mulyati, T., Pragholapati, A., 2015. HUBUNGAN BODY IMAGE DENGAN POLA DIET PADA REMAJA PUTRI DI SMAN 24 BANDUNG TAHUN 2015. http://ejurnal.stikesbhaktikencana.ac.id/file.php?file=preview_mahasiswa\&id .... 
Rosmala, I., Jundiah, S., Pragholapati, A., 2017. TINGKAT KECEMASAN PADA KELUARGA PASIEN DI RUANG ICU RSUD MAJALAYA KABUPATEN BANDUNG TAHUN 2017.

http://ejurnal.stikesbhaktikencana.ac.id/file.php?file=preview_mahasiswa\&id=517\&cd=0b2173f f6ad6a6fb09c95f6d50001df6\&name=Jurnal\%20Imas\%20Rosmala\%202017.pdf.

Septriani, D., Sari, Y.R., Pragholapati, A., 2019. The Relationship of Social Support With the Anxiety Level of Parents of Children with Thalassemia of Pre-School Age that Works in the Activities of Blood Transfusion in Hospital "X" Bandung, in: The 2nd Bandung International Conference on Collaborative Health Research Research. Prama Grand Preanger Hotel Bandung, West Java, Indonesia 7th - 8th of October 2019. p. 12.

Virgona, A., Pragholapati, A., 2019. Enhancing Critical Thinking Skills in Nursing Higher Education in Preparation for the Industrial Revolution 4.0: Literature Review, in: The 3rd International Seminar on Global Health (ISGH) "Technology Transformation in Health Care for Better Life" Bandung, West Java, Indonesia. 